\title{
A reformed perspective on taking mission and missiology to the heart of theological training
}

\begin{abstract}
Author:
Thinandavha D. Mashau ${ }^{1}$

Affiliation:

${ }^{1}$ School for Ecclesiastical Sciences, Potchefstroom Campus, North-West

University, South Africa

Correspondence to:

Thinandavha Mashau

Email:

derrick.mashau@nwu.ac.za

Postal address:

PO Box 20004, Noordbrug

2522, South Africa

Dates:

Received: 19 Oct. 2010

Accepted: 04 Aug. 2011

Published: 14 Dec. 2012

How to cite this article:

Mashau, T.D., 2012, 'A

reformed perspective on

taking mission and missiology

to the heart of theological

training', In die Skriflig/In

Luce Verbi 46(2), 8 pages.

http://dx.doi.org/10.4102/

ids.v46i2.64
\end{abstract}

C) 2012. The Authors. Licensee: AOSIS OpenJournals. This work is licensed under the Creative Commons Attribution License.
Mission and missiology have been driven to the periphery of the life of both the church and theological institutions. Missiology has, in many theological institutions in the world, struggled to find a home. It has in some instances been regarded as an intruder, in some as an interloper and in others as irrelevant. Missiology is without a doubt a voice from the margins. This article seeks to go beyond the exercise to identify reasons for such a marginalisation by looking at ways in which mission and missiology can be restored to the heart of theological education. This article reminds us that the definition and practice of missiology should be firmly grounded in the missio Dei; hence all theological disciplines should intentionally have a missionary dimension. This will in essence allow missiology to exist as an independent subject but at the same time exercise its multidimensionality. It is, therefore, critical to maintain a dynamic and creative tension between intention and dimension to understand the place of missiology in the theological encyclopaedia.

'n Gereformeerde perspektief op die neem van sending en sendingwetenskap na die hart van teologiese opleiding. Sending en sendingwetenskap is na die periferie van die lewe van sowel die kerk as teologiese instellings verdryf. Sendingwetenskap het by baie teologiese instellings gesukkel om 'n tuiste te vind. In sommige gevalle is dit as ' $n$ indringer beskou, in ander as ' $n$ tussenganger, en in sommige gevalle as irrelevant. Sendingwetenskap is sonder twyfel ' $n$ stem vanuit die buiterante. Hierdie navorsing poog om die redes vir so 'n marginalisasie te ontdek deur te kyk na maniere waarop sending en sendingwetenskap herstel kan word tot die hart van teologiese opleiding. Die artikel herinner ons dat die definisie en praktyk van sendingwetenskap stewig gegrond behoort te wees in die missio Dei, en daarom behoort alle teologiese dissiplines doelbewus ' $n$ sendingdimensie te hê. Dit sal sendingwetenskap toelaat om as 'n onafhanklike vak te bestaan en om terselfdertyd multidimensionaliteit uit te oefen. Dit is gevolglik krities om ' $n$ dinamiese en kreatiewe spanning tussen intensie en dimensie te behou om sodoende te verstaan wat die plek van sendingwetenskap in die teologiese ensiklopedie is.

\section{Introduction}

A number of theologians have called for mission and missiology to be at the heart of theology (Bosch 1982; Jongeneel 1997; Laing 2009), reminding us of a popular dictum by Kähler (in Bosch 1991:16): 'Missiology is the mother of all theology.' Theological training, in both the minority and majority worlds, has failed to live up to this expectation. Missiology has, in many theological institutions in the world, struggled to find a home. In some instances, it has been regarded as an intruder, in others as an interloper and in yet some others as irrelevant. Missiology is without doubt a voice from the margins. According to Soltau (1984):

Missiology entered the curriculum as a theological orphan to be treated generally as an addendum and looked to as a means of providing instruction in technique rather than a theology of mission. (p. 153)

The essence of the struggle for missiology as a theological discipline in theological institutions is captured in the following words by David Bosch (1982):

The gradual disappearance of missions or missiology from the curriculum of one theological institution after another further emphasises this malaise. In some of the older European and American faculties of theology where in the early part of this century missiology appeared to be firmly entrenched, the chairs have been either abolished or converted into others for world Christianity, ecumenical studies, Third World theologies, world religions and the like. (pp. 13-14)

The foregoing suggests that the future of missiology as a theological discipline is not bright. On the whole, neither the churches nor theological schools themselves welcomed the intruder. As a result, theological institutions all over the world continue to produce pastors without the vision, heart and passion for mission and church planting. Central to this problem is that both mission and missiology have been driven to the periphery in the life of both the church and theological institutions. Even when missionaries, missiologists and independent missionary agencies continue to keep up their hope about mission and missiology, they continue to meet 
resistance on the part of church and seminary leaders respectively. The following says it all: 'When the missionary flame was eventually kindled, it burned on the fringes of the institutional church, frequently meeting with passionate resistance from the official church' (Bosch 1982:17). This comes as a result of the lack of vision for world missions on the part of church and seminary leaders. In his article 'Recovering missional ecclesiology in theological education', Mark Laing (2009:11) traces back this kind of missionless ecclesiology that saw no necessity for the inclusion of missiology in the theological curriculum to the Christendom in the West. When the majority of Western countries were considered to be Christian, they isolated themselves from engaging with the wider world and as a result developed an abnormal theology that relegated mission and missiology to the periphery. Jongeneel (1997:10) concurs with Laing when he notes, amongst others, that 'Western theology has lost its missionary nature and has delegated mission issues and mission studies to missionaries and missiologists.' The same observation by Jongeneel is relevant for institutions in the majority world because this defective ecclesiology, which was introverted in its outlook, was exported to these countries; hence institutions from the South also struggle with the problem of integrating mission and missiology in their theological training.

Apart from the reason identified by Laing and supported by Jongeneel above, secularism and liberalism in theology in theological institutions can be cited as the real reason for the marginalisation of mission and missiology. Where theological institutions fan the flame of genuine Spirit-filled godliness, they continue to send out missionaries by the hundreds just as Calvin did from Geneva by sending out more than a thousand missionaries who planted about 2000 churches over a period of 20 years. We need to ask: What was there in the theology of Calvin and the reformers that has lead to the most effective missions and church planting since Pentecost? What do we lack, causing our theological efforts not to result in the same zeal for missions?

This problem will continue until such time that the supremacy of God and his mission are taken serious in the life of both churches and seminaries. This brings us to the main research question of this article: What can be done to take mission and missiology to the heart of theological training?

Our main research question presupposes that missiology belongs at the heart of theological training and that it should be treated as such. The foregoing calls, therefore, for a serious reorientation of missiology as a theological discipline. In order to answer the above-mentioned question, this article will therefore look closely at the definition of missiology and its place in the theological encyclopaedia. The critical role that missiology plays in shaping and molding theological training and theological students will be outlined in the process, and practical examples and suggestions will be provided as to how best missiology can be taken back to the heart of theological training.

\section{Missiology revisited Missiology defined}

A thorough study of the body literature in the field of missiology suggests that missiologists have had different perspectives on the name and definition of this theological discipline. Kuyper, for example, preferred the use of the words apostolics and prosthetics whilst Bavinck preferred the word science of missions for the name (Bavinck 1960:xvii; cf. Visser 2003:81). For the purpose of this article, the word missiology is preferred, and it can be used interchangeably with the words science of missions because the two concepts intentionally retains the notion of being sent.

As for the definition, Kritzinger (1987:4) defined missiology simply as a science of mission or the study of mission. Verkuyl, in contrast, defined missiology as 'the study of salvation activities of the Father, Son and Holy Spirit throughout the world geared towards the bringing of God into existence'. The definition provided by Kritzinger is simple and straightforward in terms of outlining how we should understand missiology as a theological discipline, and it is complemented by the definition by Verkuyl. Verkuyl's definition is grounded more on the work of the triune God as a missionary God who is actively involved in his created world. In line with the spirit of missional theology and in an effort to find a working definition for the purposes of this article, missiology can therefore be defined as a theological reflection and study on God's mission and God's command and calling of the church to participate in that mission by witnessing to the coming of God's kingdom. Our understanding of the kingdom will determine our approach to missions and the scope of our study of missions (missiology). This is well captured in the new statement of faith of the World Reformed Fellowship (World Reformed Fellowship 2011):

Our mission in the world flows from our passion for the glory of God and our assurance of the coming of his kingdom. The church as the community of Christ, is God's instrument of evangelism, which is the preaching and sharing of the gospel of Jesus Christ, through both words and deeds, that Christ died for our sins and was raised from the dead according to the Scriptures, and that $\mathrm{He}$ as the reigning Lord now offers forgiveness of sin, eternal life and gifts of the Spirit to all who repent and believe. In obedience to the commission of our God, we have to present two hands to all people: (1) the hand calling them to repentance, faith and eternal reconciliation with God through Christ, and (2) the hand manifesting deeds of mercy and compassion, extending the goodness of God's kingdom on earth in the name of Christ. This is the example given to us by Christ himself and proclaims that we are conformed to the image of Christ and have received the Holy Spirit as the first fruits and guarantee of God's new creation. (p. 18)

\section{Missiology as a theological discipline}

According to Bosch (1982:14), the study of mission as an academic discipline is of recent origin. This is a clear attestation that missiology as a theological discipline has been sidelined from the theological encyclopaedia for long 
and continues to struggle to find a home as already noted in the introduction. As would be expected, the marginalisation and neglect of mission by the church were reflected in the isolation, neglect, and marginalisation of missiology in theological education (Laing 2009:13). The classical theological curriculum includes courses in biblical studies, systematic theology, church history and practical theology to the exclusion of missiology. This became a pattern that still dominates curriculum formation in many theological institutions in both the majority and minority worlds.

Whilst the first incumbent of a chair in missiology, Breckenridge, was appointed at Princeton Seminary in 1836 (Bosch 1982:14), it was Warneck who was amongst the first to justify the inclusion of missiology in the theological curriculum when he was appointed as professor at the University of Halle in 1896. Two reasons are cited for such a position. The first refers to the historical fact that missions had become important in the modern world and that it could be of great service in the encounter between diverse peoples; the second is based on the theological principle that the idea of missions is an integral part of the saving revelation in Christ (Bavinck 1960:xviii). The struggle for missiology to find a home in theological institutions is made manifest by the fact that, until 1950, there were only 71 lecturing posts for missiology in different protestant theological institutions and universities worldwide, with 51 of those in the United States of America (Du Plessis 1960:1; cf. Bosch 1982:15). The problems of a lack of vision for world missions and compartmentalisation in as far as the theological curriculum is concerned can be cited as main reasons for this development.

As for the place of missiology within the theological encyclopaedia, missiologists hold different views. Kuyper placed missiology in the didascalic group because of its concern with education and the ministry of the Word. Following in his footsteps, but holding a slightly different view, Bavinck placed missiology in the diaconological group (Bavinck 1960:xx; cf. Visser 2003:84). Therefore, both Kuyper and Bavinck were comfortable with placing missiology under practical theology. The South African reformed missiologist Hugo du Plessis followed the same line of placing missiology under practical theology (Mashau 2008:172). This article seeks to affirm the position held by Bosch who noted that missiology should stand as an independent discipline of theology, but at the same time be integrated in other theological disciplines. Missiology, therefore, must take into account both the missionary dimension and the missionary intention; it must be both a complementary yet independent science. The discussion on the practice of missiology below will continue to shed some light on this position.

\section{The divisions of missiology}

Missiology as a theological discipline is divided into diverse elements of study and research, and missiologists have taken different approaches in dealing with this matter. Bavinck distinguished three main areas of concern for missiology, namely theory of missions, elenctics and history of missions (Bavinck 1960:xxi; cf. Visser 2003:78). In his two voluminous encyclopaedias Philosophy, science, and theology of mission in the 19th and 20th centuries, Jongeneel also divided mission studies into three branches, namely the philosophical study of mission, the empirical study of mission and the theological study of mission. The approach by both Bavinck and Jongeneel remind us that there are four critical elements that must be taken into consideration whenever an attempt is made to provide divisions of missiology, namely (1) the historical context (mission history); (2) the biblical text (mission and the text); (3) the theological foundation (the encounter between mission and the text); and (4) the world context (the scope of mission and approach). These divisions will also have subdivisions like methodology, anthropology, apologetics and so on.

\section{The theological character of mission}

\section{The object and principium}

The importance and meaning of missiology should be seen in the light of its theological character. This position has been weakened by the emergence of the 19th century subjectivism and relativism. Subjectivism and relativism were emphasised over against the authority and the inspiration of the Word of God. There is no absolute truth, truth can only be viewed as subjective and relative (Du Plessis 1960:2). Over and against these growing tendencies of subjectivism and relativism, Barth through his dialectic approach to the theology of religions brought about the understanding that the Word of God should be our starting point as we engage ourselves with theology. This had a great influence within the protestant circles. Kraemer came to an antithetical conclusion that the non-Christian religions must be confronted with the revelation of God in Christ (Du Plessis 1960:3). According to Bavinck, however, Barth's rejection of the general revelation and absolute position of antithesis can never be a solution to the problem created by subjectivism and relativism in the 19th century. If the authority and inspiration of the Word of God is denied or questioned, then theology is under attack at its very heart (Du Plessis 1960:4). The Word of God is the basis of theology as a science. It should be seen as the only object and principium cognoscendi of the theological science or knowledge. It is therefore imperative to bear this in mind when engaging with theology due to the growing tendency in our times to undermine the authority of Scripture.

\section{Theological foundation of missiology}

The foundation of missiology could be best understood in terms of four dimensions, namely Trinitarian, Christological, Pneumatological and Eschatological. These dimensions are grounded on the concept of missio Dei with the church as the instrument of God's mission to the world (Du Plessis 1960:6). It is therefore imperative to look at each one of these dimensions separately in order to depict what is embedded in each one of them.

The Trinitarian foundation: The Triune God is a missionary God. The three persons in the Trinity are all actively involved in history as a missionary God, the only true God who is Lord of the entire creation and all of humanity. The primary basis, however, is not to be found in the Triune God's involvement 
in the history of mankind as a missionary God but in his divine decrees as agreed upon in the eternal council of God as depicted by Kuyper or Voetius. The Trinitarian foundation of missiology found its basis in the divine will of the Triune God (Du Plessis 1960:7).

The Christological foundation: The Christological foundation of mission reminds us not only of salvation in and through Christ, but of his Lordship which must be communicated when the church participates in the missio Dei. According to Broocks (2002:64), Jesus is the Kurios, the absolute supreme authority. Sinners must therefore be called to submit to Christ as their new Lord and King. This is a profound message that must be communicated in mission. Without it, the mission of the church becomes meaningless and a fruitless exercise, and it leads to churches filled with Christians who do not significantly differ from other people in the world as far as lifestyle is concerned.

Pneumatological foundation: The Holy Spirit applies the redemptive work of Christ in the lives of the believers. The Holy Spirit equips the believers with the necessary gifts to proclaim the Word of God. He also empowers them to preach the Word in word and deed with boldness. He calls, equips and empowers individual believers for their missionary work in the world. Through the preaching of the gospel, the Holy Spirit gathers the church of God from eternity to eternity. One of the most prominent and distinctive features in reformed missiology is that the Spirit does not only work in the hearts of individuals, but also in the larger context of the world. Pneumatology is not only concerned with one's heart and faith, but also with experiencing the world and discovering God's footprints in the created order as outlined in the creation mandate (Gn 1:28). Today, the battle is to safeguard this truth against a derailment of pluralism. Man can partake in God's salvation without naming Christ (through the work of the Spirit in all religions!). The unique Lordship and salvation in and through Christ must be proclaimed in our Christian witness.

The Eschatological foundation: Theologians like Cullmann, Freytag and Hartenstein developed the theological foundation of missiology from an eschatological perspective. The first and second coming of Christ are seen in terms of the history of salvation as qualifying the coming of the kingdom of God as a present reality and one yet to come. Through the mission of the church, something of the future coming kingdom of God is realised. Our emphasis in this regard has to do with the coming of the basileia, the kingdom. In the salvation history of the church, the eschatological dimension reminds us of the fact that the Christ-centred church is the heir of the kingdom of God. The mission of the church is, therefore, to be directed towards the nations with an eye to the coming of Christ and his kingdom. This understanding is based on the fact that the church is founded by the King and exists for him. The church is therefore the covenantal people of the King, and it should also be understood as the eschatological church, which is not only in principle differentiated from the world because of her holiness, but also reckoned as the kingdom church awaiting the final coming of the basileia. She stands as witnesses of the King, under the authority of her Lord as the light and salt of all of life, and that is why she is entrusted with the responsibility of proclaiming the gospel with word and deed (Mt 5:16) to all peoples of the world (Du Plessis 1960:15). Christ himself instituted the relationship between mission and eschatology in Matthew 24:14 and Luke 24:46-49. The good news of the kingdom will first be proclaimed to the whole world and then the end will come.

The South African reformed missiologist Hugo du Plessis notes four aspects in connection with the relationship between eschatology and mission:

1. The proclamation of the gospel of the kingdom of God is not only a sign of the end but also a sign that the end has broken through. Something of the future is realised now. The coming of Christ and the fulfilment of his mission on earth were indeed a breaking through of the kingdom of God (Du Plessis 1960:18).

2. The proclamation of the gospel of the kingdom of God brings about an assurance and guarantee that the coming of the kingdom in its final state is certain. Believers are sure of it through that which they can realise in the present reality. It is therefore imperative for the church to proclaim the salvation in Christ with word and deed and modelling a transformed lifestyle to the world so that all can be attracted to come under his Lordship (Zch 8:23; Is 60:3; Acts 2:49; 13:47, 48; 1 Cor 14:25). Mission is therefore an earthly manifestation of the ushering in of the kingdom of God (Du Plessis 1960:18).

3. The proclamation of the gospel in terms of the coming of the kingdom of God is the total essence and meaning of the church's proclamation to the world. Christ's command in Mathew 28:18-20 clearly communicates that it is a command that has in mind the totality of reality. The church is sent to the end of the world and the ages, to all nations, each day till the end comes and all should be taught to uphold this (Du Plessis 1960:19).

4. The proclamation of the gospel to the end of the earth, Israel included (Rm 9-11), is a sign of the end. He notes, however, that it is not the work of the church, that is to say bringing the gospel to the end of the earth that will bring about the end of times but the sovereign will of God. The end of times is the work of the triune God Himself who brings about the total or perfect renewal of his creation and the world so that Christ will become everything to all (see Eph 1:20-23; cf. Du Plessis 1960:20).

\section{The practice of missiology}

David Bosch's contribution in this regard must be appreciated. In his article 'Theological Education in Missionary Perspective', Bosch (1982) proposed that missiology needs to be both dimensional (i.e. integrated into and in close dialogue with biblical studies, church history, systematic theology and practical theology) and intentional in creating a critical distance from the other disciplines, bringing its own distinctive perspectives to bear on the theological task. It is therefore critical to maintain a dynamic and creative tension 
between dimension and intention (Bosch 1982:25). When the church gathers on a Sunday, her intention is to worship God, but the meeting with God should have a missionary dimension. Hence, it is critical that elements in the worship service should be organised to be seeker-friendly and at the same time God centred (1 Cor 14:25). In this instance, the celebration of the Holy Communion can be used as an example. The meaning of and the reason why the Holy Communion is celebrated should be explained to members and seekers alike. The celebration of the Holy Communion is intended for confessing believers and, therefore, intentionally excludes non-believers, but at the same time, such exclusion serves as an invitation to those non-believers to come to faith if well explained. We declare in evangelism that one day everything will stand under his feet (Eph 1:22; 1 Cor 15:25-28; Heb 2:7-8), and we fall at these same feet in worship (1 Cor 14:24-25). This in essence provides the missionary dimension of the celebration of the Holy Communion. The same can be said about the fellowship, diaconal service and preaching. According to Pachuau (2000), attempts were made within ecumenical circles since the early 1950s to interpret proclamation, service and fellowship as the means of witnessing to the Gospel. The same should happen when doing theology. Those of us who are involved in theological training should understand that the nature and scope of mission and missiology is as wide as God's redemptive acts. Missiology can therefore not be limited to the study of evangelism, church planting and church growth in the so-called mission field or missionary situations. Missiology covers the entire scope of theology without relegating all of theology to mission and missiology. Missiology has the function to provide scientific description and analysis of the life of the church in the past and in the present, but at the same time, it provides a normative critical function with regard to the future of the church and the manner in which the church should conduct its activities towards that future. The distinction between dimension and intention is therefore critical for understanding this perspective.

In the article cited above, Bosch succeeded in providing a broader framework as to how best missiology could be related to theological disciplines such as systematic theology, church history, practical theology, biblical theology and ecumenics. This article seeks to go further by providing tangible examples as to how the integration of the missiological dimension can be accomplished.

\section{Biblical studies and biblical languages}

The area of biblical studies and biblical languages in the theological encyclopaedia provides space and ground to deal with the text and original languages through which the text was received. Academics who deal with biblical and ancient languages such as Hebrew, Greek and Latin are able to bring the missionary dimension into their areas by teaching students to appreciate (1) languages as gifts from God; (2) languages are a useful tool to communicate God's salvific acts in history; and that (3) we learn ancient and biblical languages so that we are able to understand the text and its message better to enable us to communicate the gospel to our generation in a much clearer way. An introductory article that provides the rationale as to why it is necessary for theologians to study ancient and biblical languages can go a long way in providing the missiological dimension in this regard. As for Old Testament and New Testament scholars, their scope is much broader in terms of the possibilities of integrating missiology in their disciplines:

1. Service to the missio Dei should serve as one of the hermeneutical keys to help us understand the biblical text. According to Kritzinger (1987:7), 'The missio Dei is the hermeneutical key which opens the Bible for Missiology.' The reading of the biblical text should therefore be done taking into consideration that God is a missionary God who, through the communicated text, is reaching out to humanity as He advances his Kingdom on earth.

2. A missiological reading of the text is therefore critical and it can be achieved by asking students to identify missiological issues in their Old and New Testament surveys and exegetical studies. The reading and interpretation of the biblical text of the Old and New Testaments should be an exercise that seeks to trace the footprints of the missionary God who has 'the heart for the gospel and the heart for the world', in the words of Paul Visser (2003).

God's creation, the election of Israel, God's covenant, the exodus account, the election of Abraham and the promise that he would be the father of all nations and the promise of the servant of the Lord in the biblical text are clear testimony that the missionary God was actively involved in mission from the beginning, hence the Old Testament should be regarded as a missionary text just like the New Testament. The recording of the life history and ministry of Jesus Christ, the calling of the disciples, the Pentecost events, the new covenant of grace and the clear marching orders to the church to be God's witnessing community to the very end of the age are a clear testimony that the New Testament is a missionary text. The reading of both the Old and the New Testament should serve the gospel to the fullest, lest it becomes a void academic exercise that only enhances human knowledge.

\section{Ecclesiology}

According to Kritzinger (1987:7), 'Missiology as the study of the church-in-mission (missio ecclesiae) comes very close to Ecclesiology, which is an area of Systematic Theology.' Academics dealing with subjects such as church history, church and dogma history and church polity should bear in mind that the church and the missio ecclesiae were born out of the missio Dei and, therefore, this understanding is critical in defining the being of a local and universal church of God, matters which are more relevant in the field of church polity. The church by its very nature is a missionary church, a witnessing community of God. This missionary ecclesiology has direct implications with regard to:

- the manner in which we understand the being of the church today

- the manner in which issues of church planting, church renewal or revitalisation and growth are conducted 
- the relationship between the mother and younger churches is defined

- the manner in which issues of offices and sacraments are dealt with from a missional perspective

- issues of diversified ministry (including the most critical question on tent-making ministry) must be addressed from church polity perspective

- the reading of church history will be different.

The church in mission will always seek to trace the history of the Christian church in mission with an eye to learn from the past and avoid the mistakes of the past as they forge ahead to bring the gospel to this current generation in faith. The benefits of introducing the missionary dimension into church history are well captured by the following words of Bosch (1982):

The introduction of the missionary dimension into church history could open new perspectives on such neglected issues as the question of the failure of the early church to win the Jewish people to Christ; the attitudes to 'heretics' in the church after Constantine, particularly to those outside the Roman Empire such as the Nestorians and Monophysites; the disappearance almost without trace during the 7th century of the church in once highly Christianized North Africa, Arabia and the Near East, and the ensuing virtual immunization of Islam against the gospel; and the official attitude of the church to the enslavement of non-Christians, the subjugation and exploitation of other races and the attendant phenomenon of conversion by coercion. (p. 28)

Bosch's contribution to view the history of the Christian church from a missionary perspective is just an example as to how this good intention can best be achieved. Asking how Christians in every epoch in the history of the Christian church approached people of other faiths remains critical in bringing missiology to heart of church history.

\section{Dogmatology}

Jongeneel (1997:49) uses the term mission[ary] dogmatics to refer to dogmatic theory of mission and continues to highlight the fact that dogmatics can only be considered as a missionary dogmatics when it treats mission as an essential component. There are ample opportunities for scholars of dogmatics to bring mission and missiology to the heart of dogmatics. These are the following:

1. In dogmatics, doctrines such as those of God, of the fall of humanity, of soteriology, of the covenant, of the Kingdom of God, of the eschatology and of Pneumatology, amongst others, involve missionary thoughts that must be contextualised.

2. The contextualisation of Christian doctrines such as those cited above will remain critical. According to Bosch (1982:27-28), 'It is undeniable that the teaching of systematic theology and the published works in this field almost completely lacked this dimension of involvement in the world until two decades ago.' The process of contextualisation will require the introduction of more practical missionary case studies in the teaching of dogmatics.

3. Dialogue and serious engagement between the West and the majority world is needed, especially because most of the textbooks used in the teaching of dogmatics are coming from the West. Theological and practical issues that arise in the encounter between the gospel and adherents of other religions such as the African Traditional Religion(s), Scientology, Hinduism and Islam should receive serious attention in the teaching of dogmatics. Missionary apologetics as an interdisciplinary subject that integrates both missiology and dogmatics is a clear testimony as to how best the missionary dimension can be achieved in the field of dogmatics.

Missionary ethics is one other subject under dogmatology that can go a long way in dealing with ethical questions that missionaries have evaded in the past, namely the question of human sexuality, marriage and family (especially the question of polygamy in the African context), ethics of tribalism, racism, ethics of creation and culture (ecological issues), political ethics and the lavish lifestyle on the side of missionaries over against indigenous people. Efforts to address these thorny and critical ethical issues will go a long way in bringing mission and missiology to the heart of ethics as a theological subject.

\section{Practical theology}

According to Bosch (1982:29), 'The discipline of practical theology all too frequently does not exceed domesticated reflections on the self-realisation of the institutional church in its preaching, liturgy, teaching ministry, pastorate and diaconal work.' It is regrettable that theological institutions in the majority world have followed the same pattern as the West. Missiology has an important role to play in turning churches from being inward looking to missional churches, churches that exist for non-members. Missiology may indeed help practical theology to learn anew what it means to be the church of Jesus Christ in the context of the world. There are ample opportunities for practical theologians to bring mission and missiology to the heart of practical theology:

1. In missionary catechetics (Jongeneel 1997:213), children's and youth ministry are approached from a missionary perspective. This is critical in this generation where children and the youth are the majority of many populations with the latter constituting a new frontier for the Christian church as far as witnessing is concerned. This is also the area wherein the role of Christian education can be addressed with all the seriousness it deserves. The goal of catechetical instruction and education will no longer be limited to the transference of knowledge but also to the formation of character and lifestyle that brings glory to God in whatever the young citizens of this world do.

2. In missionary liturgics (Jongeneel 1997:241), the worship service is structured to reflect not only cultural sensitivity but also missionary consciousness or awareness towards seekers or non-believing visitors. Contextual relevant music and issues concerning the use of musical instruments and dancing must be dealt with from a missionary perspective. This will include issues of continuity and discontinuity with African traditional religious beliefs and systems, that is, symbols, art and rituals. The question of worship and ancestral veneration will be addressed with 
all seriousness if we are serious about true reformation in the African context (this will apply to many countries in the majority world). The question of the place of healing in the worship service will also be addressed, and this is critical in the age of the pentecostalisation of Christianity in the majority world.

3. In missionary homiletics (Jongeneel 1997:267), evangelistic preaching will be restored to the pulpit to bring back the fire of the gospel in the life of churches. All sermons delivered in church and missionary services must be evangelistic, the kerygma [announcement of the good news and invitation to repentance]. Both the preaching of Jesus and that of Paul and other apostles are considered to be direct missionary preaching, hence Jongeneel (1997:276) considers the apostolic preaching as the paradigm of missionary preaching;

4. In missionary poimenics (Jongeneel 1997:291), pastoral care can be dealt with from a missiological perspective. Jongeneel uses the term missionary poimenics to describe the systematic study of the missionary office and functions of the poimen, the pastor, the shepherd. Accordingly, missionary poimenics establishes, in the framework of the missio Dei, a standard of Christian pastorate amongst non-Christians in diverse contexts (Jongeneel 1997:292). The connection between mission and pastoral care is therefore not only critical in bringing missiology to the heart of pastoral care, but also a very challenging task that we cannot ignore or undermine. This includes areas of pastoral counselling, especially in the intercultural and/or cross-cultural contexts. Knowledge and personal relationship with the chief pastor or shepherd Jesus Christ is central if missionary poimenics is to bear fruits.

5. In missionary diaconics (Jongeneel 1997:307), Christian service is rendered to both Christians and non-Christians. This is more than just ministry fulfilled by ordained deacons. It includes issues of development (socioeconomic development). A course in missionary service and development is critical in theological institutions in the majority world where issues of poverty and community upliftment are critical. This is the area where questions regarding inter-church aid and cooperation with other religions with regard to development issues are seriously critiqued. The question of solidarity with the poor and the oppressed (or the marginalised) should be dealt with under missionary diaconics (Jongeneel 1997:316). This will go a long way in bringing mission and missiology to the heart of theological training.

\section{Mission at the heart of theological training: Practical suggestions}

The above-mentioned call of taking mission to the heart of theological training can be achieved if the following practical suggestions are taken into consideration:

- A paradigm shift with regard to the purpose of doing theology is needed. If we clearly see that the marginalising of missions and missiology in theology is a symptom of a blurred focus on God then there will not only be a reorientation of missiology as a theological discipline, but the whole goal of all theological disciplines will have to be refocused on God and true worship, adoration and honour and praise of his name. We need to emphasise at this point that it is not just about an academic discipline missiology, but it is a lack of true God centeredness and a sense of amazement and wonder about the One who has been given all power in heaven and earth that have blurred the great commission in academic theologising. Theology that does not stir up doxology will never fan the flame of missions! The function of theology therefore is to equip the church to become stunned, amazed and filled with amazement and wonder about their awesome God (Soli Deo Gloria). Piper is right when he says that the whole spectrum of theological education is failing to achieve the most crucial outcome of all pastoral training. This outcome should be that every theological lecturer, pastor and missionary should know God more personally in all his majesty, supremacy and glory than they know anything else and that they find their greatest joy in him (Piper 2003).

- The supremacy of God needs to be rediscovered in the practice of theology. The doctrine of God should therefore be taught with explicit reference to God's missional character. It will help us to understand, in our efforts to bring mission and missiology to the heart of theology, that the mission of the church is not an end in itself. The mission of the church serves the missio Dei and, therefore, the worship and glorification of God is its ultimate goal. According to Piper, worship not mission is ultimate because God is ultimate, not man. When this age is over and the countless millions of the redeemed fall on their faces before the throne of God, missions will be no more. It is a temporary necessity. Worship, however, abides forever (Piper 2003):

Worship, therefore, is the fuel and goal in missions and ministry. It's the goal of missions because in missions we simply aim to bring the nations into the white-hot enjoyment of God's glory. The goal of missions is the gladness of the peoples in the greatness of God. 'The Lord reigns; let the earth rejoice; let the many coastlands be glad!' (Ps 97:1). 'Let the peoples praise Thee, O God; let all the peoples praise Thee! Let the nations be glad and sing for joy!' (Ps 67:3-4; p. 17)

- We need a paradigm shift with regard to the manner in which we understand the concept church. The nature of the church is nothing but God's missionary people. This is a reformed missional ecclesiology which is grounded in the missio Dei, with the church as an instrument participating in the mission of God. The teaching of the doctrine of the church should emphasise the missional character of the church as the community sent by God into the world to extend the mission of Jesus.

- We need a paradigm shift with regard to the church's responsibility towards theological training. Any model of theological training must take place within the context of the church. Theological institutions cannot do theological training, especially ministerial formation, in isolation from the church. The needs of the local church must be taken serious. We must be conscious of the fact that all of 
theology is to serve the life and witness of the church and that the church can exist as a church only when dedicated to the mission of God. This kind of understanding has implications for the teaching staff. Professors must be ministers of the Word who are still actively involved in ministry on a part-time basis like Calvin in Geneva.

- With regard to student formation, a discipleship model of training should be our option. This is a model informed by the priority of shaping the head, heart and hands of all theological students, thereby enabling them to be faithful witnesses of Christ on earth (fishers of men). The teaching of theology should therefore be intentional about the implications of theology for holistic personal formation. We must be conscious of the fact that our efforts in theological training are to equip and enable God's missionary people for service in the kingdom of God. The teaching of theology should therefore give explicit attention to the ways in which theology functions in the formation of an authentic missional community.

- Internships must be an integral part of theological training. Local churches must be used as laboratories where students can learn through field experience. More case studies, which encourage students to be in touch with the context of the day, should be integrated in the curriculum and monitored accordingly.

- The reorientation of the theological curricula is critical. The teaching of theology should be intentional in orienting all topics of theology in relation to the biblical truth of the mission of God and its variegated witness to this mission in a variety of genres.

\section{Conclusion}

It can be concluded without fear of contradiction that the exercise to bring mission and missiology to the heart of theological training is neither a battle for supremacy nor one that seeks to turn all of theology into missiology and the entire theological training into a missionary school. It is not even a battle to lower the academic standard. This is the battle to turn theology and theological training into doing things in a new way, one that takes the missio Dei as its raison d'être. The reaffirmation of the missional ecclesiology will lead to the affirmation of the missional theology, one that places mission and missiology at the heart of theological education. The entire curriculum of theological training should therefore be missional, permeated by our theological understanding of God's mission and the missionary nature of the church as an instrument participating in the mission of God to advance his kingdom. Integrating mission and missiology into the heart of theological training is not a problem if all educators share in the common vision and are committed to God's mission.

\section{Acknowledgements Competing interests}

The author declare that he has no financial or personal relationship(s) which may have inappropriately influenced him in writing this article.

\section{References}

Bavinck, J.H., 1960, An introduction to the science of missions, P\&R Publishing, Phillipsburg, New Jersey.

Bosch, D.J., 1982, 'Theological education in missionary perspective', Missiology X/1, 13-33.

Bosch, D.J., 1991, Transforming mission: Paradigm shifts in theology of mission, Orbis, New York.

Broocks, R., 2002, Every nation in our generation: Recovering the apostolic mandate, Struik Christian Books, Cape Town.

Du Plessis, H., 1960, Die missiologie as 'n teologiese wetenskap, PU vir CHE, Potchefstroom.

Jongeneel, J.A.B., 1997, Philosophy, science, and theology of mission in the 19th and 20th centuries: A missiological encyclopedia, Part 2, Missionary theology, Peter Lang, Frankfurt.

Kritzinger, J.J., 1987, 'Introducing Missiology', in H.L. Pretorius, A.A. Odendal, P.J. Robinson \& G. Van der Merwe (eds.), Reflecting on mission in the African context, pp. 1-10, Pro Christo Publications, Bloemfontein.

Laing, M., 2009, 'Recovering missional ecclesiology in theological education', International Review of Mission 98(1), 12-24. http://dx.doi.org/10.1111/j.17586631.2009.00002.x

Mashau, T.D., 2008, Following Jesus outside the camp: The missionary legacy of Hugo du Plessis, AcadSA, Kempton Park.

Pachuau, L., 2000, 'Missiology in a pluralistic world: The place of mission study in theological education', International Review of Mission 89(355), 539-555. http:// theological education', International Review of M
dx.doi.org/10.1111/j.1758-6631.2000.tb00243.x

Piper, J., 2003, Let the nations be glad! The supremacy of God in missions, Baker, Grand Rapids.

Soltau, A.P., 1984, 'Mobilizing the seminaries', in H.M. Conn (ed.), Reaching the unreached: The old-new challenge, pp. 149-166, Presbyterian and Reformed Publishing Company, Phillipsburg.

Visser, P.J., 2003, Heart for the gospel, heart for the world: The life and thought of a reformed pioneer Missiologist Johan Herman Bavinck [1895-1964], Wipf and Stock Publishers, Eugene.

World Reformed Fellowship, 2011, Promoting reformed partnerships worldwide, viewed 25 October 2012, from http://www.wrfnet.org/c/document library/get file?folderld=20\&name=DLFE-46.pdf 